\title{
Perceived knowledge, attitude towards HIV/ AIDS, and sexual behavior among migrant workers in Malaysia: a structural path analysis
}

Md M. Rahman, Mohd T. Arif, Razitasham Safii, Zainab Tambi, Zulkifli Jantan, Mohd F. Ismail

Universiti Malaysia Sarawak, Malaysia

\begin{abstract}
Background: Acquired immuno-deficiency syndrome (AIDS) continues to be a public health challenge. Migrant workers are vulnerable to indulge in high-risk health behaviors. In this context, we analyzed the impact of perceived knowledge and attitude towards human immunodeficiency virus (HIV)/AIDS on sexual behavior among migrant workers in Sarawak, Malaysia.

Material and methods: Data of 314 migrant workers were collected via face-to-face interview, using a cross-sectional structured questionnaires. Data analysis were done using Stata version 16.0; however, a structural equation model was developed and evaluated with WarpPLs, version 7.0.

Results: Hypothetical model of sexual behavior, and perceived knowledge and attitude towards HIV/ AIDS were investigated in the present study. Analysis revealed that both directly and indirectly mediated through attitudes towards HIV/AIDS influence sexual behavior $(p<0.05)$. Moreover, attitude towards HIV/AIDS directly influenced sexual behavior $(p<0.05)$. However, knowledge of HIV/AIDS transmission did not affect sexual behavior $(p>0.05)$. Multivariate analysis showed that construction workers $(p<0.05)$ and daily wage $(p<0.001)$ had an impact on HIV and AIDS knowledge. Type of job such as farming $(p<0.05)$, daily wage $(p<0.05)$, and HIV and AIDS knowledge had an impact on attitude towards HIV and AIDS. However, type of job and daily wage appeared to be significant predictors of sexual behavior.

Conclusions: Although this study did not describe overall sexual behavior scenario among migrant workers, the findings could support guidelines and policies to developed awareness-creating packages, including HIV/AIDS behavior change communication. That would help to diminish HIV/AIDS vulnerability among migrant workers.
\end{abstract}

HIV AIDS Rev 2021; 20, 3: 213-222

DOI: https://doi.org/10.5114/hivar.2021.109631

Key words: sexual behavior, knowledge, attitude, migrant workers, Bangladesh, Sarawak, Malaysia.

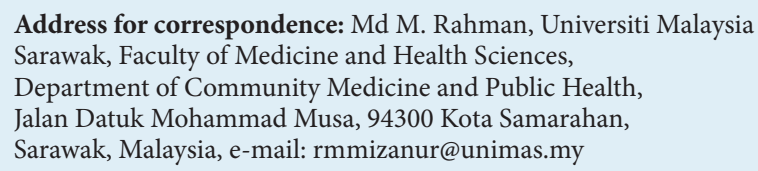

Address for correspondence: Md M. Rahman, Universiti Malaysia Sarawak, Faculty of Medicine and Health Sciences, Department of Community Medicine and Public Health, Jalan Datuk Mohammad Musa, 94300 Kota Samarahan, Sarawak, Malaysia, e-mail: rmmizanur@unimas.my

Article history:

Received: 22.07.2020

Received in revised form: 03.12.2020

Accepted: 11.12.2020

Available online: 30.08 .2021
International Journal of HIV-Related Problems

HIV \& AIDS

Re vi e w 


\section{Introduction}

Globally, human immunodeficiency virus (HIV) infection and acquired immunodeficiency syndrome (AIDS) epidemic remain a significant public health concern as worldwide as in Malaysia. In 2017, the United Nations Joint Programme on HIV/AIDS (UNAIDS) estimated almost 2 million newly HIV-diagnosed people that make up nearly 37 million people worldwide living with HIV [1]. In Malaysia, there was a total of nearly 100,000 people living with HIV, and around 3,397 of new HIV cases were detected in 2016 [1].

Rapid economic development indicates that Malaysia is on a course to establish itself as a developed country. Job and economic opportunities in Malaysia are the pulling factors for foreigners to migrate to Malaysia. The entrance of foreign workers into this country has benefited Malaysia in boosting its high productivity and income with low-cost labors. Statistics shows that in 2017, around 1.8 million foreign workers were employed in Malaysia, with $40 \%$ from Indonesia, $22 \%$ from Nepal, and $14 \%$ from Bangladesh [2]. In the same year, the number of Bangladeshi workers in Malaysia was approximately 250,000 . However, the above data involved only those who entered the country legally, omitting those undocumented. Bangladeshi workers are mainly involved in manufacturing, construction, and agriculture sectors.

Every foreign worker to be brought working in Malaysia, undergoes a strict medical check-up. Pre-employment medical screening at their hometowns certify and ensure that all migrants workers are fit and healthy from infectious disease, which can significantly threat the health status of the host population. Malaysian policy recommended that each worker passes a second medical examination conducted by panel clinics within 30 days after arrival in Malaysia [3]. Foreign workers would not be permitted to enter and work in Malaysia, if he or she failed to appear on medical examination, as stated under section 8 of the Immigration Act of 1959/1963 [3]. Even though migrant workers undergo a stringent medical procedures, at the same time, they are vulnerable to HIV

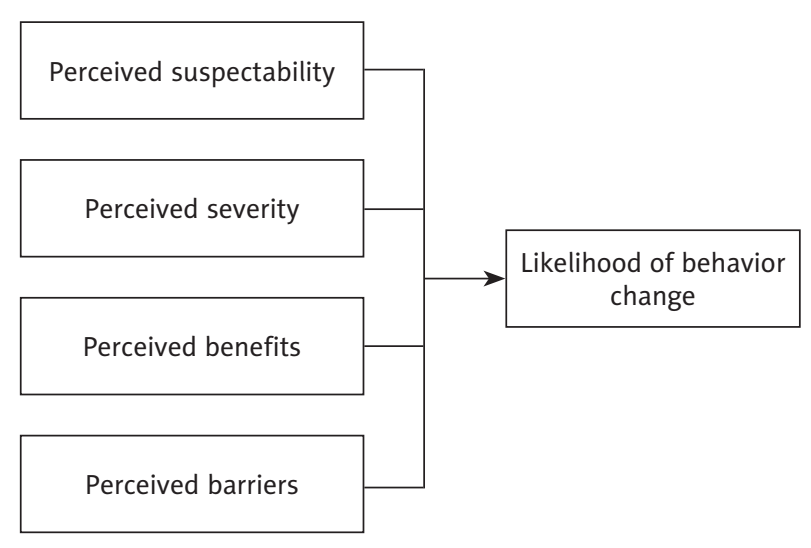

Figure 1. Schematic diagram of theoretical framework according to health belief model infection. About $4 \%$ of the country's total percentage of HIV infections are attributable to foreigners [1].

Many factors contribute to HIV infection among migrant workers. They are required to travel alone and leave their partners in the country of origin. As stated in the Immigrant Act of Malaysia, foreign workers are not permitted to arrive with their families or spouses [4]. However, migrant workers are at an increased risk for unsafe sexual practice, contact with sex workers, and aggravate sexually transmitted diseases. Although, the current study did not performed tests for sexually transmitted diseases status, the results from this research can be used by policymakers or public health practitioners, to develop effective programs or policies promoting migrant workers' sexual health. In this context, we developed a structural model of migrant worker sexual behavior and analyzed the impact of knowledge and attitude towards HIV/AIDS on sexual behaviors.

\section{Theory and hypothesis development}

In a study, Rosenstock et al. [5] published health belief model (HBM), which followed an individual's notorious failure to accept preventive disease measures, including screening test. HBM permits to understand that individual beliefs and perception towards disease or risk, influence a personal decision regarding own health. HBM has already been utilized as a theoretical framework for HIV/AIDS prevention program. Four main components influence the likelihood of an individual to change own behavior, as illustrated in Figure 1. All of the perceived components are influenced by adequate knowledge and attitude towards disease or risk [6]. The proposed conceptual framework used in this study is shown in Figure 2.

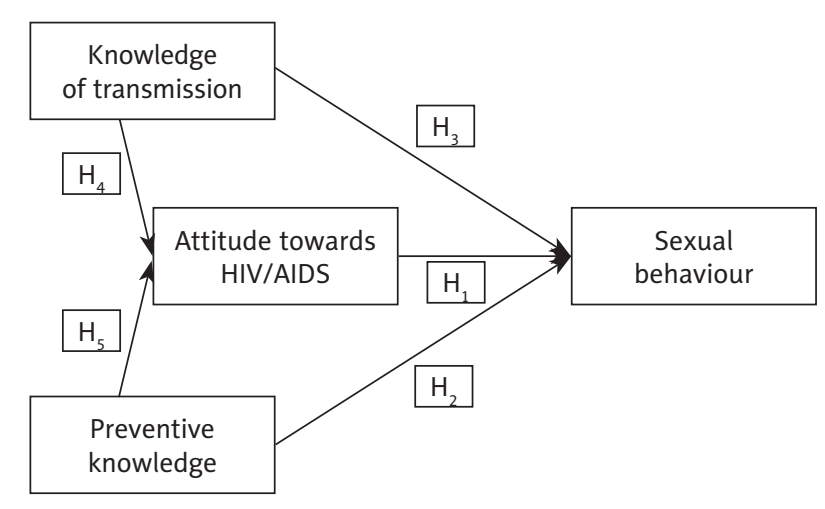

Figure 2. Proposed conceptual framework. The hypothesis to be tested include: H1: Attitude towards HIV/AIDS that is positively related to sexual behavior. H2: HIV/AIDS preventive knowledge that is positively related to sexual behavior. H3: Knowledge of HIV/AIDS transmission that is negatively related to sexual behavior. $\mathrm{H} 4$ and $\mathrm{H} 5$ : Knowledge of transmission or HIV/AIDS preventive knowledge, which had a mediated effect on sexual behavior through attitude towards HIV/AIDS 


\section{Material and methods}

\section{Setting and population}

Data from 314 Bangladeshi migrant workers in Sarawak were analyzed using cross-sectional study design. We collected data from adult workers aged 18 years and above living in their workplaces. To test the impact of perceived knowledge and attitude towards HIV/AIDS on sexual behavior, we developed a hypothetical model of sexual behavior. The sample size was calculated based on an estimated prevalence of self-reported morbidity. The prevalence of morbidity was considered as a base prevalence as $36.4 \%$ [7], with standard error not greater than 0.03 [8] for the calculation of sample size. Therefore, the total sample size was 401 migrant workers, including a $10 \%$ of non-response rate.

\section{Variables and data collection}

Sexual behavior was obtained with three questions: 1 . 'Sex with others than safe and single partner'; 2. 'Sex with others than wife in Malaysia'; 3. 'Sex with men (MSM)'. Answer options included ' 0 ' score for 'No', 1 score for 'Do not want to disclose', and 2 scores for 'Yes'.

Knowledge of transmission of HIV/AIDS was evaluated with four matters: 1. 'HIV can be spread through sexual intercourse'; 2. 'HIV can be transmitted from mother-to-child'; 3. 'HIV can be spread by sharing needle or syringe'; 4. 'HIV can be transmitted through blood transfusion'.

Preventive knowledge of HIV/AIDS was assessed with four questions: 1. 'No needle and syringe sharing can prevent HIV'; 2. 'HIV can be avoided by using condom properly during sexual intercourse'; 3 . 'HIV transmission can be prevented by staying loyal to single-spouse'; 4. 'Blood test before marriage would help preventing HIV transmission'.

Four questions to evaluate attitude towards HIV/AIDS included: 1. 'If one of your HIV-positive relative/friends become sick, would you be willing to take care of him/ her at home or in your neighborhood?'; 2. 'If your friend is HIV-positive, would you support this friendship?'; 3. 'If a student is HIV-positive, should he/she be allowed to continue his/her schooling?'; 4. 'If a teacher is HIV-positive, should he/she resume his/her teaching in school?'. The questions had three answers options, including 'Yes', 'No', and 'Not sure'.

Instruments for data collection were established using patient satisfaction questionnaire [9] and relevant other previous instruments $[10,11]$. The whole questionnaire was English-written, translated into Bangla (language of Bangladesh), and pre-tested before actual field operation in a non-sample region. One student from Bangladesh was assigned to collect the data, who gathered the information through face-to-face interviews. The data collection was performed at a convenient time during weekend.

\section{Data entry and analysis}

The collected data were verified for inconsistencies, incomplete responses, etc., with a team leader cross-checking any missing or non-response questions. Information from the completed questionnaires were entered into a Microsoft Excel 2016 sheet. Before proceeding to confirmatory model testing, multivariate skewness and kurtosis were checked $[12,13]$ using STATA, version 16.0 [14]. The results showed significant multivariate skewness $(\beta=405.0789 ; p<0.001)$ and kurtosis $(\beta=1053.5305 ; p<0.001)$. Data collection continued with partial least squares (PLS) technique and a structural path equation model developed for the study. We used partial least squares (PLS) methodology using WarpPls, version 7.0 software [15], for the analysis of the model. Measurement model in terms of convergent and discriminating validity was evaluated, followed by structural model analysis to test the study's hypothesis $[15,16]$. Results were presented in path diagram with tabular information of path coefficients, loading by bootstrapping method and according to Hair et al. [13]. A multiple linear regression analysis was performed to identify the predictors of knowledge, attitude towards HIV and

Table 1. Characteristics of the respondents

\begin{tabular}{|c|c|c|}
\hline Characteristics & Frequency & $\begin{array}{c}\text { Percentage/ } \\
\text { mean }\end{array}$ \\
\hline Age in years (mean, SD) & 314 & $35.9(7.3)$ \\
\hline \multicolumn{3}{|l|}{ Religion } \\
\hline Islam & 308 & 98.1 \\
\hline Hinduism & 6 & 1.9 \\
\hline \multicolumn{3}{|l|}{ Marital status } \\
\hline Single & 48 & 15.3 \\
\hline Married & 266 & 84.7 \\
\hline \multicolumn{3}{|l|}{ Level of education } \\
\hline No formal education & 49 & 15.6 \\
\hline Primary & 106 & 33.8 \\
\hline Secondary & 136 & 43.3 \\
\hline Higher secondary & 23 & 7.3 \\
\hline \multicolumn{3}{|l|}{ Nature of job } \\
\hline Farming & 6 & 1.9 \\
\hline Construction & 101 & 32.2 \\
\hline Manufacturing & 135 & 43.0 \\
\hline Other & 72 & 22.9 \\
\hline \multicolumn{3}{|l|}{ Type of salary payment } \\
\hline Daily & 258 & 82.2 \\
\hline Monthly & 56 & 17.8 \\
\hline Median monthly income (RM) & 314 & 923.0 \\
\hline Number of dependents (median) & 314 & 4.0 \\
\hline $\begin{array}{l}\text { Duration of work in Malaysia } \\
\text { (years) }\end{array}$ & 314 & 10.0 \\
\hline
\end{tabular}


Table 2. Convergent validity

\begin{tabular}{|c|c|c|c|c|c|c|}
\hline Constructs/Items & Loadings & $\alpha$ & Dijkstra-R & CR & AVE & VIF \\
\hline \multicolumn{7}{|l|}{ Sexual behavior } \\
\hline G2_A & 0.909 & \multirow[t]{3}{*}{0.865} & \multirow[t]{3}{*}{0.870} & \multirow[t]{3}{*}{0.917} & \multirow[t]{3}{*}{0.787} & \multirow[t]{3}{*}{1.469} \\
\hline G6_A & 0.894 & & & & & \\
\hline G9_A & 0.857 & & & & & \\
\hline \multicolumn{7}{|c|}{ Attitude towards HIV/AIDS } \\
\hline F1 & 0.940 & \multirow[t]{4}{*}{0.942} & \multirow[t]{4}{*}{0.946} & \multirow[t]{4}{*}{0.958} & \multirow[t]{4}{*}{0.851} & \multirow[t]{4}{*}{2.435} \\
\hline $\mathrm{F} 2$ & 0.893 & & & & & \\
\hline $\mathrm{F} 4$ & 0.934 & & & & & \\
\hline F5 & 0.923 & & & & & \\
\hline \multicolumn{7}{|c|}{ Knowledge on transmission } \\
\hline E1 & 0.800 & \multirow[t]{4}{*}{0.892} & \multirow[t]{4}{*}{0.910} & \multirow[t]{4}{*}{0.926} & \multirow[t]{4}{*}{0.757} & \multirow[t]{4}{*}{2.205} \\
\hline E2 & 0.884 & & & & & \\
\hline E3 & 0.908 & & & & & \\
\hline E4 & 0.884 & & & & & \\
\hline \multicolumn{7}{|c|}{ HIV/AIDS preventive knowledge } \\
\hline E10 & 0.924 & \multirow[t]{4}{*}{0.974} & \multirow[t]{4}{*}{0.974} & \multirow[t]{4}{*}{0.981} & \multirow[t]{4}{*}{0.927} & \multirow[t]{4}{*}{3.108} \\
\hline E11 & 0.975 & & & & & \\
\hline E12 & 0.983 & & & & & \\
\hline E13 & 0.968 & & & & & \\
\hline
\end{tabular}

AIDS, and sexual behavior among migrant workers, using STATA version 16.0 [14].

\section{Ethical issues}

Due to sensitiveness of the questions, we assured for data confidentiality. The participants were briefed about the objectives of the study, and their voluntary participation was sought. A written informed consent was taken from every participant before the interview.

\section{Results}

\section{Characteristics of the migrant workers}

The mean (SD) age of the workers was 35.9 years (median, 7.3 years), with minimum age of 24 years and maximum age of $60.98 .1 \%$ of the workers were Muslim and the majority were married (84.7\%). Out of 314 workers, $43.3 \%$ had secondary level of education, followed by primary level of education (33.8\%), with $15.6 \%$ having no formal education. More than two-fifths (43\%) of the workers were engaged in manufacturing job (43\%), followed by construction (32.2\%) works, and a variety of jobs according to employers' desires (22.9\%). The majority of workers $(82.2 \%)$ operated on a dailypaid basis, and only $17.8 \%$ had a monthly salary. The median monthly income was MYR 923, with maximum MYR 2,000 and minimum MYR 520. More than half of the workers had monthly income ranging from MYR 900 to MYR 1,300. At least 4 participants depended on self-earning. The median duration of working in Malaysia was 10 years, with a maximum of 21 years (Table 1 ).

\section{Convergent validity}

Items, such as loadings, average variance extracted (AVE), Cronbach's $\alpha$, and composite reliability $[17,18]$ were considered. In the study, convergent validity of the constructs established as the item loadings reported were higher than 0.70 . The analysis showed convergent validity of the constructs with the item loadings higher than 0.70 , and composite reliabilities were higher than 0.70 , with model AVE higher than 0.50. [19]. Table 2 illustrates convergent validity.

\section{Discriminant validity}

Three criteria were examined, including Fornell-Larcker criterion, which indicated square root of average variance extracted (AVE) greater than correlation of the construct with all other constructs of the structural model [20]. Table 2 indicates diagonal values of AVE square root. Off-diagonal elements were correlations among the constructs. Diagonal elements should be greater than off-diagonal values.

The second criterion was cross-loading, which was boldfaced in each construct, which was greater than other cor- 
Table 3. Discriminant validity

\begin{tabular}{|c|c|c|c|c|}
\hline Criterion & 1 & 2 & 3 & 4 \\
\hline \multicolumn{5}{|l|}{ Fornell-Larcker criterion } \\
\hline Sexual behavior (1) & 0.887 & & & \\
\hline Attitude towards AIDS (2) & 0.515 & 0.923 & & \\
\hline Knowledge on transmission (3) & 0.339 & 0.629 & 0.870 & \\
\hline HIV/ AIDS preventive knowledge (4) & 0.522 & 0.738 & 0.721 & 0.963 \\
\hline \multicolumn{5}{|l|}{ Cross-loading } \\
\hline G2_A & 0.909 & 0.510 & 0.301 & 0.466 \\
\hline G6_A & 0.894 & 0.370 & 0.195 & 0.406 \\
\hline G9_A & 0.857 & 0.494 & 0.411 & 0.521 \\
\hline F1 & 0.485 & 0.940 & 0.626 & 0.716 \\
\hline F2 & 0.371 & 0.893 & 0.552 & 0.611 \\
\hline F4 & 0.490 & 0.934 & 0.584 & 0.719 \\
\hline F5 & 0.553 & 0.923 & 0.558 & 0.673 \\
\hline E1 & 0.196 & 0.467 & 0.800 & 0.460 \\
\hline E2 & 0.344 & 0.542 & 0.884 & 0.664 \\
\hline E3 & 0.293 & 0.534 & 0.908 & 0.655 \\
\hline E4 & 0.337 & 0.642 & 0.884 & 0.716 \\
\hline E10 & 0.558 & 0.715 & 0.677 & 0.924 \\
\hline E11 & 0.492 & 0.739 & 0.722 & 0.975 \\
\hline E12 & 0.489 & 0.703 & 0.720 & 0.983 \\
\hline E13 & 0.475 & 0.684 & 0.657 & 0.968 \\
\hline \multicolumn{5}{|l|}{ Heterotrait-monotrait ratio (HTMT) } \\
\hline \multicolumn{5}{|l|}{ Sexual behavior (1) } \\
\hline Attitude towards AIDS (2) & 0.571 & & & \\
\hline Knowledge on transmission (3) & 0.386 & 0.685 & & \\
\hline HIV/ AIDS preventive knowledge (4) & 0.571 & 0.770 & 0.770 & \\
\hline
\end{tabular}

responding items. However, there was a criticism over Fornell-Larcker and cross-loading of the constructs [16], with low sensitivity. An alternative approach was multitrait-multimethod matrix to determine discriminant validity in the context of heterotrait-monotrait (HTMT) ratio of correlations [16]. If a HTMT value was greater than HTMT0.85 of 0.85 [21] or HTMT0.90 of 0.90 [22], then discriminant validity was not established. However, our results showed that it was less than HTMT cut-off value, and therefore, discriminant validity could be considered established. Table 3 illustrates discriminant validity.

\section{Hypothesis testing results}

\section{Model fit and quality indices}

Robust path analysis, with a non-linear algorithm and bootstrapping re-sampling method was used for analysis [15]. Model fitting and quality indices indicated that average

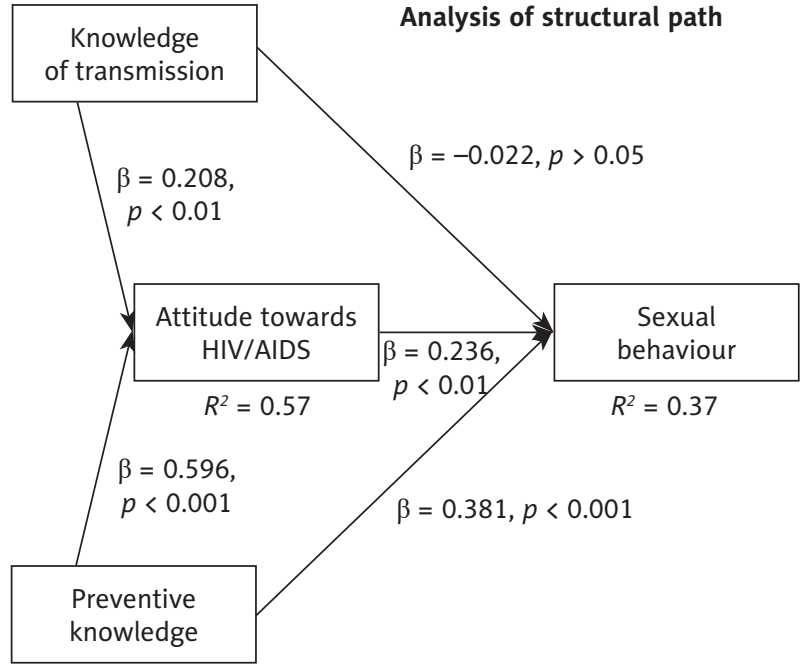

Figure 3. Bootstrapping hypothesis testing 
Table 4. Results of hypothesis testing

\begin{tabular}{l|l|c|c|c|c|c|c|c|c|c}
\hline Hypothesis & \multicolumn{1}{|c|}{ Relationship } & $\begin{array}{c}\text { Std. } \\
\text { beta }\end{array}$ & $\begin{array}{l}\text { Std. } \\
\text { error }\end{array}$ & $2.5 \%$ & $97.5 \%$ & $t$-value & $\begin{array}{c}R^{2} \\
\text { contribution }\end{array}$ & $Q^{2}$ & ES & Decision \\
\hline $\mathrm{H} 1$ & $\begin{array}{l}\text { Attitude towards } \\
\text { PLWHA and sexual } \\
\text { behavior }\end{array}$ & 0.286 & 0.110 & 0.071 & 0.501 & $2.604^{* *}$ & 0.152 & & 0.152 & Supported \\
\hline $\mathrm{H} 2$ & $\begin{array}{l}\text { HIV/AIDS preventive } \\
\text { knowledge and } \\
\text { sexual behavior }\end{array}$ & 0.381 & 0.136 & 0.115 & 0.648 & $2.801^{* *}$ & 0.214 & 0.333 & 0.214 & Supported \\
\hline $\mathrm{H} 3$ & $\begin{array}{l}\text { Knowledge } \\
\text { of transmission and } \\
\text { sexual behavior }\end{array}$ & 0.022 & 0.129 & -0.231 & 0.275 & 1.169 & 0.008 & & 0.008 & $\begin{array}{c}\text { Not } \\
\text { supported }\end{array}$ \\
\hline $\mathrm{H} 4$ & $\begin{array}{l}\text { Knowledge } \\
\text { of transmission and } \\
\text { attitude towards } \\
\text { PLWHA }\end{array}$ & 0.208 & 0.096 & 0.021 & 0.395 & $2.175^{*}$ & 0.131 & & 0.131 & Supported \\
\hline $\mathrm{H} 5$ & $\begin{array}{l}\text { HIV/ AlDS preventive } \\
\text { knowledge and } \\
\text { attitude towards } \\
\text { PLWHA }\end{array}$ & 0.596 & 0.101 & 0.398 & 0.794 & $5.901^{* * *}$ & 0.443 & 0.579 & 0.443 & Supported \\
\hline
\end{tabular}

${ }^{*} p<0.05,{ }^{* *} p<0.01,{ }^{* * *} p<0.001$. ES - effect size: small (0.02), medium (0.15), and large (0.35).

path coefficient was $0.299(p<0.001)$, average $R^{2}$ was 0.474 $(p<0.001)$, average adjusted $R^{2}$ was $0.469(p<0.001)$, average block VIF was 2.017, average full collinearity VIF was 2.305, Tenenhaus GoF was 0.627 , standardized root mean squared residual was 0.070 , and standardized mean absolute residual was 0.055 . All model fitting information indicated a well-fitted model.

\section{Knowledge of HIV/AIDS sexual transmission to influence sexual behavior}

There has been a negative relationship between understanding of HIV/AIDS transmission and migrants' sexual behaviors. High knowledge of migrants allowed low-risk behaviors, but statistically, the relationship was not significant. A migrant's attitude towards a person with HIV/AIDS created full mediation of the relationship between knowledge of HIV/ AIDS sexual transmission and sexual behavior among migrants workers (Table 4).

\section{HIV/AIDS preventive knowledge to influence migrants' sexual behaviors}

HIV/AIDS prevention knowledge positively influenced migrants' sexual behaviors. This indicated that though the workers had sufficient HIV/AIDS preventive knowledge on HIV/AIDS, their sexual behaviors remained a high-risk. The correlation between HIV/AIDS preventive knowledge and sexual behavior among migrants was statistically signifi- cant. As migrants' attitudes toward a person with HIV/AIDS indicated a mediation, it created partial mediation between HIV/AIDS preventive knowledge against sexual behaviors of migrants (Table 4).

\section{Attitude towards a person with HIV/AIDS to influence sexual behaviors of migrants}

Those migrant workers, who had the right attitude towards people living with HIV/AIDS were vulnerable to high-risk sexual behaviors. These results show an attitude towards people living with HIV/AIDS as positively correlated and statistically significant, with high-risk sexual behaviors among migrant workers (Table 4).

\section{Indirect and total effect}

Analysis of the indirect and total effect of different parameters on sexual behavior are illustrated in Table 5 . The evaluation indicated that HIV/AIDS preventive knowledge had a substantial impact on sexual behavior (ES, 0.552; $p<0.001)$. Similarly, HIV/AIDS preventive knowledge presented a huge influence on attitude towards HIV/AIDS (ES, 0.596; $p<0.001)$. However, HIV/AIDS knowledge of transmission had no significant impact on sexual behavior (ES, $0.290 ; p>0.05$ ), and a small effect on attitude towards HIV/ AIDS (ES, 0.208; $p<0.05$ ). The analysis revealed that attitude towards HIV/AIDS had an impact on sexual behavior (ES, 0.286; $p<0.01$ ). 
Table 5. Indirect and total effects of sexual behavior

\begin{tabular}{l|c|c|c|c|c}
\hline Parameters & Indirect & $p$-value & Total & $p$-value & VAF \\
\hline Sexual behavior attitude towards HIV/AIDS & - & - & $0.286^{* *}$ & 0.005 & - \\
\hline Sexual behavior of HIV/AIDS preventive knowledge & 0.170 & 0.010 & $0.552^{\star * *}$ & 0.001 & $30.79 \%$ \\
\hline $\begin{array}{l}\text { Sexual behavior knowledge of HIV/AIDS } \\
\text { transmission }\end{array}$ & 0.059 & 0.049 & 0.081 & 0.290 & $72.84 \%$ \\
\hline Attitude knowledge of HIV/AIDS transmission & - & - & $0.208^{*}$ & 0.015 & - \\
\hline Attitude preventive knowledge of HIV/AIDS & - & - & $0.596^{* * *}$ & 0.001 & - \\
\hline
\end{tabular}

${ }^{*} p<0.05,{ }^{* *} p<0.01,{ }^{* * *} p<0.001$. ES - effect size: small (0.02), medium (0.15), and large (0.35). VAF-variance accounted for indirect effect/total effect ${ }^{\star} 100$

Table 6. Factors affecting knowledge, attitude, and sexual behavior: multiple linear regression analysis

\begin{tabular}{|c|c|c|c|c|c|c|}
\hline \multirow[t]{2}{*}{ Variables } & \multicolumn{2}{|c|}{ Knowledge } & \multicolumn{2}{|c|}{ Attitude } & \multicolumn{2}{|c|}{ Behavior } \\
\hline & Beta & SE & Beta & SE & Beta & SE \\
\hline Age in years & -0.001 & 0.021 & -0.007 & 0.011 & 0.001 & 0.008 \\
\hline \multicolumn{7}{|l|}{ Marital status } \\
\hline Single (Ref.) & 0.000 & & 0.000 & & 0.000 & \\
\hline Married & 0.040 & 0.400 & 0.093 & 0.211 & 0.046 & 0.161 \\
\hline \multicolumn{7}{|l|}{ Education } \\
\hline \multicolumn{7}{|c|}{ No formal education (Ref.) } \\
\hline Primary & 0.336 & 0.413 & 0.051 & 0.218 & 0.079 & 0.166 \\
\hline Secondary & 0.435 & 0.409 & 0.066 & 0.216 & 0.007 & 0.165 \\
\hline Higher secondary & 0.036 & 0.617 & 0.314 & 0.326 & 0.312 & 0.248 \\
\hline \multicolumn{7}{|l|}{ Type of job } \\
\hline Farming & -1.164 & 0.998 & $1.234^{\star}$ & 0.528 & $-2.009^{* * *}$ & 0.406 \\
\hline Construction & $0.923^{*}$ & 0.384 & 0.011 & 0.204 & $0.422^{* *}$ & 0.156 \\
\hline Manufacturing & -0.312 & 0.344 & -0.018 & 0.182 & $0.348^{*}$ & 0.138 \\
\hline Other (Ref.) & 0.000 & & 0.000 & & 0.000 & \\
\hline \multicolumn{7}{|l|}{ Salary } \\
\hline Daily & $3.424^{\star \star \star}$ & 0.370 & $0.501^{*}$ & 0.221 & $0.882^{\star \star *}$ & 0.170 \\
\hline Monthly (Ref.) & 0.000 & & 0.000 & & & \\
\hline \multicolumn{7}{|l|}{ Duration of stay } \\
\hline$<10$ (Ref.) & 0.000 & & 0.000 & & 0.000 & \\
\hline $10-14$ & -0.142 & 0.288 & 0.294 & 0.152 & 0.016 & 0.117 \\
\hline$\geq 15$ & 0.086 & 0.745 & -0.285 & 0.393 & 0.171 & 0.300 \\
\hline Knowledge & - & - & $0.297^{* * *}$ & 0.030 & $0.121^{* * *}$ & 0.027 \\
\hline Attitude & - & - & - & - & 0.037 & 0.044 \\
\hline Constant & $6.305^{* * *}$ & 0.916 & $0.727^{\star \star *}$ & 0.520 & $-0.023^{*}$ & 0.397 \\
\hline F-ratio & \multicolumn{2}{|c|}{$(11,302)=13.26^{\star \star \star}$} & \multicolumn{2}{|c|}{$(12,301)=16.60^{\star * *}$} & \multicolumn{2}{|c|}{$(13,300)=16.44^{* * *}$} \\
\hline Adj. $R^{2}$ & \multicolumn{2}{|c|}{0.3012} & \multicolumn{2}{|c|}{0.3743} & \multicolumn{2}{|c|}{0.3904} \\
\hline
\end{tabular}

Factors affecting knowledge, attitude, and sexual behavior: multiple linear regression analysis

To determine the factors affecting knowledge, attitude, and sexual behavior, a multiple linear regression analysis was completed, in which dependent variables were continuous
(Table 6). Independent variables included age, marital status, level of education, type of work, type of payment, and duration of stay in Malaysia. Exploratory data analysis revealed that there was no potential outliers and multi-collinearity. F-ratio and adjusted $R^{2}$ showed a well-fitted model. Moreover, the analysis demonstrated that construction work- 
ers $(p<0.05)$ and daily wage $(p<0.001)$ had an impact on knowledge of HIV and AIDS. In terms of preventive attitude, farming as the type of job $(p<0.05)$, daily wage $(p<0.05)$, and knowledge of HIV and AIDS had an impact on attitude towards HIV and AIDS. However, analysis of sexual behavior, type of job, daily wage, and knowledge of HIV and AIDS appeared to be significant predictors of sexual behavior. Age, marital status, level of education, and duration of stay in Malaysia had no impact on knowledge, attitude, and sexual behavior $(p>0.05)$ of migrant workers.

\section{Discussion}

Due to the complexity of migrants' sexual behaviors, there was no perfect model to describe all aspects of this health matter. Health belief model (HBM) is mostly used in health promotion and education, and it is used to identify factors influencing sexual behavior [24]. Therefore, we hypothesized HBM to further understand this issue [23]. The objectives of the study were to assess the structural model of sexual behavior and perceived knowledge and attitude towards HIV/AIDS among migrant workers in Malesia. Attitude, knowledge on transmission, and HIV/AIDS preventive knowledge among the study predictors can influence sexual behavior among migrant workers.

\section{Migrant sexual behavior}

This research shows that Bangladeshi migrant sexual behavior is influenced by preventive knowledge on HIV/ AIDS, and attitude towards persons living with HIV/AIDS. High understanding of HIV prevention and correct attitude towards people living with HIV/AIDS, have a positive correlation with sexual behavior among migrant workers. Knowledge and attitude can create awareness of HIV diseases. Khani Jeihooni et al. [25] supported our findings and reported that excellent knowledge and attitude towards HIV and AIDS create proper awareness. Therefore, the awareness could affect sexual behavior, which indicate that education influentially and indirectly affected sexual behavior through knowledge and attitude. However, our study revealed that knowledge of HIV transmission did not change sexual behavior among Bangladeshi migrants. This means that even if a person was well-equipped with knowledge on HIV/AIDS transmission, this would not prevent from engaging in sexual activity. This was supported by Tang et al. [26], who reported that sexual-related knowledge increased the odds for pre-marital sexual intercourse, which could be explained by the fact that HIV infection has a long latent period, and infected person may remain asymptomatic and unaware of the disease for some time [27, 28]. Furthermore, HIV/AIDS poor knowledge and how they can be transmitted to another persons can lead to sexual promiscuity [25]. Tarkang and Pencille [29] reported no statistical relationship between sexual behavior and transmission knowledge on HIV/ AIDS, which correlates with the present study.
However, Wang et al. [30] and Yang et al. [31] described that majority of migrant workers had good knowledge, but were still engaged in high-risk sexual activity. Another study performed among Myanmar migrant workers in Thailand showed that adequate HIV knowledge did not prevented them from demonstrating high-risk behavior, including unsafe sex and multiple sexual partners [32]. Loganathan et al. [33] found that insufficient sexual and reproductive knowledge as well as no local health facilities and contraception accesses have lead migrant workers to promiscuity. Dahal et al. [34] in Nepal observed that most of returnee migrants from Malaysia and Middle Eastern countries reported high HIV awareness, with many of them having sex during their working period, and $20 \%$ of them not using contraceptives. Low-risk perception towards HIV/AIDS leads to continuation of sexual activity, even with the awareness that HIV is transmitted through unprotected sex and multiple sexual partners [35]. These findings disagree on the fact that high understanding and knowledge of HIV/AIDS may not necessarily exclude a person to have risky sex. Najimudeen et al. [36] in Malaysia found that there is low awareness on HIV and AIDS among migrant workers, especially those from Indonesia, Nepal, and Bangladesh. This might be due to non-accessibility of local HIV/AIDS awareness campaign.

\section{Attitude towards a person living with HIV/AIDS}

A person living with HIV/AIDS may be an important source for transmitting the diseases into community [36]. Another finding from this study demonstrated that Bangladeshi migrants' understanding of the diseases' transmission and preventive measures positively correlated with their attitude towards a person living with HIV/AIDS [37]. Most of the literature supported a view that lack of HIV knowledge leads to an increased avoidance and stigma among people living with HIV/AIDS [38, 39]. However, the knowledge alone does not change a person's attitude towards HIV-infected individual. Previous studies showed that despite a high level of knowledge, there still was a high negative attitude towards a person with HIV/AIDS [40, 41]. Kuete et al. [42] observed that people prefer to stay away from HIV-positive person, despite having good knowledge on the disease itself.

Stigma and discrimination can lead a person to have a high emotional stress, poor health-seeking behavior, and more non-disclosure of HIV status to healthcare providers. By having good knowledge on transmission and preventive measures, an individual can be well-equipped with information on how to deal with a person infected with HIV. Such an individual would have no discrimination and stigmatized attitude towards those with HIV. Better knowledge and awareness of HIV infection identified by Arrey et al. [43] and Vorasane et al. [44] reduce stigma and discrimination for HIV-infected persons. A source of some confusions about HIV transmission include likelihood of HIV transmission through using the same utensils, public toilets, 
and physical interactions, such as hand-shaking. Poor attitude towards people living with HIV and AIDS (PLWHA) would create missed opportunity for education, HIV transmission knowledge, and poor treatment compliance. Ruiz et al. [45] illustrated that migration itself is one of the determinants of HIV infection transmission, with reasons including changes in migrant's behavior norms, long distance from spouse, family and social support, and poor economic status. Therefore, migrants remain in constant increased risk of mixing with local population and getting involved in high-risk behaviors, such as illegal drug use, alcohol abuse, and random sex.

Onlya minimal percentage of migrants use condoms during sexual intercourse. Similar results were found by Amirkhanian et al. [46] and Weine et al. [47]. Knowledge of HIV/AIDS among migrants can influence increased use of condoms [48]. For instance, it was reported that among West African migrants, higher HIV knowledge significantly predicted use of condoms [49]. In the context of health belief model (HBM), those who had inadequate knowledge on transmission and preventive practices, they were prone to face barriers to change their behaviors [50]. Examples of perceiving barriers towards HIV include fear of HIV test positive result, poor HIV/AIDS knowledge, and lack of preventive health behaviors. However, a higher concern among migrants was limited by financial resources for screening or treatment of HIV infection [51].

The present study had some limitations. Firstly, we used cross-sectional data that measured HIV/AIDS knowledge and attitude at one point in the time of the study. Secondly, knowledge and/ or attitude might be changed due to exposure to AIDS-related information in a new environment. Thus, statistically significant variables might change at another point in time. Thirdly, there might be underreporting of sexual behavior due to sensitiveness of the questions.

\section{Conclusions}

Overall, the results of this study show that preventive knowledge, attitude towards a person living with HIV/ AIDS, and knowledge on HIV/ AIDS transmission analyzed with health-belief model (HBM), influence sexual behavior among migrant workers in Malesia.

\section{Acknowledgements}

This study was conducted by a grant of Nusantara Chair from Institute of Borneo Studies, Universiti Malaysia Sarawak (Ref.: F05/(NRC)/1335/2016) [1].

The authors would like to express their gratitude to the Institute of Borneo Studies (IBS) and Faculty of Medicine and Health Sciences (FMHS), Universiti Malaysia Sarawak (UNIMAS), for approval and financial support for the research. We are grateful to the Universiti Malaysia Sarawak (UNIMAS) ethics committee for ethics approval (UNIMAS/ NC-21.02/03-02(13). Moreover, we would like to thank all the responders who participated in the study as well as the fel- lows collecting the data. We are grateful to Professor Dr Andrew Kiyu for his insightful remarks and editing of the manuscript.

\section{Conflict of interest}

The authors have no conflict of interest.

\section{References}

1. Malaysian AIDS Council, Malaysian AIDS Foundation. Snapshot of HIV \& AIDS in Malaysia 2016 [Internet]. 2016. Available from: https://www.mac.org.my/v3/resources/hiv-statistics/.

2. Ministry of Home Affairs. Jumlah Pekerja Asing Mengikut Jantina dan Negara Sumber - MAMPU [Internet]. 2018. Available from: http://www.data.gov.my/data/ms_MY/dataset/jumlah-pekerjaasing-plks-aktif-mengikut-jantina-dan-negara-sumber.

3. Immigration Department of Malaysia. Recruitment Terms and Conditions of Foreign Workers [Internet]. 2019 [cited 2019 Feb 14]. Available from:https:/www.imi.gov.my/index.php/en/foreign-worker. html.

4. Malaysia. Laws of Malaysia. Act 155 - Immigration Act 1959/63. Percetakan National Malaysia Berhad; 1995.

5. Rosenstock IM. Historical origins of the Health Belief Model (HBM). Health Educ Monogr 1974; 2: 328-335.

6. Tarkang EE, Zotor FB. Application of the Health Belief Model (HBM) in HIV Prevention: A Literature Review. Cent Afr J Public Health [Internet]. 2015 [cited 2019 Feb 15]; 1: 1. Available from: http://www.sciencepublishinggroup.com/journal/paperinfo. aspx?journalid=326\&doi=10.11648/j.cajph.20150101.11.

7. Peng Y, Chang W, Zhou H, Hu H, Liang W. Factors associated with health-seeking behavior among migrant workers in Beijing, China. BMC Health Serv Res 2010; 10: 69.

8. Wejnert C, Pham H, Krishna N, Le B, DiNenno E. Estimating design effect and calculating sample size for respondent-driven sampling studies of injection drug users in the United States. AIDS Behav 2012; 16: 797-806.

9. Rahman MM, Shahidullah M, Shahiduzzaman M, Rashid HA. Quality of health care from patient perspectives. Bangladesh Med Res Counc Bull 2002; 28: 87-96.

10. Kapusta J, Schöffel L, Gogolishvili D, Globerman J. Rapid Response Service. Migrant Farm Workers and Sexual Health. [Internet]. Ontario HIV Treatment Network; 2013. Available from: https:// pdfs.semanticscholar.org/96d0/25f86aclfcfa88c0e7166a79d8779cd69ae4.pdf.

11. Thanavanh B, Rashid MHO, Kasuya H, Sakamoto J. Knowledge, attitudes and practices regarding HIV/AIDS among male high school students in Lao People's Democratic Republic. J Int AIDS Soc 2013; 16: 17387.

12. Cain MK, Zhang Z, Yuan KH. Univariate and multivariate skewness and kurtosis for measuring nonnormality: prevalence, influence and estimation. Behav Res Methods 2017; 49: 1716-1735.

13. von Hair JF, Hult GTM, Ringle CM, Sarstedt M. A Primer on Partial Least Squares Structural Equation Modeling. $2^{\text {nd }}$ ed. SAGE Publications, Inc; 2016.

14. Stata Corp. Stata Statistical Software [Internet]. College Station, Texus, USA: StataCorp LLC; 2019 [cited 2020 Jun 20]. Available from: https://www.stata.com/company/.

15. Ned Kock. WarpPLS user manual: Version 7.0. Laredo, Texas, USA: ScriptWarp Systems; 2020.

16. Henseler J, Ringle CM, Sarstedt M. A new criterion for assessing discriminant validity in variance-based structural equation modeling. J Acad Mark Sci [Internet]. 2015 [cited 2019 Jan 5]; 43: 115135. Available from: https://doi.org/10.1007/s11747-014-0403-8. 
17. Gholami R, Sulaiman AB, Ramayah T, Molla A. Senior managers' perception on green information systems (IS) adoption and environmental performance: Results from a field survey. Inf Manage [Internet]. 2013 [cited 2019 Jan 5]; 50: 431-438. Available from: http://www.sciencedirect.com/science/article/pii/ S0378720613000724.

18. Taghizadeh SK, Amran A, Ahmad NH, Rahman SA. Supporting entrepreneurial business success at the base of pyramid through entrepreneurial competencies. Manag Decis [Internet]. 2015 [cited 2019 Jan 5]; 53: 1203-1223. Available from: https://www.emeraldinsight.com/doi/abs/10.1108/MD-08-2014-0531.

19. Hair JF, Black WC, Babin BJ, Anderson RE. Multivariate Data Analysis. $7^{\text {th }}$ ed. United Kingdom: Pearson Education Limited; 2014.

20. Fornell C, Larcker DF. Evaluating Structural Equation Models with Unobservable Variables and Measurement Error. J Mark Res [Internet]. 1981 [cited 2019 Jan 5]; 18: 39-50. Available from: https:// www.jstor.org/stable/3151312.

21. Kline RB. Principles and Practice of Structural Equation Modeling: [Internet]. Fourth. New York: The Guilford Press; 2015 [cited 2019 Jan 5]. Available from: https://www.guilford.com/books/Principles-and-Practice-of-Structural-Equation-Modeling/Rex-Kline/ 9781462523344.

22. Gold AH, Malhotra A, Segars AH. Knowledge Management: An Organizational Capabilities Perspective. J Manag Inf Syst [Internet]. 2001 [cited 2019 Jan 5]; 18: 185-214. Available from: https:// doi.org/10.1080/07421222.2001.11045669.

23. Yakubu I, Garmaroudi G, Sadeghi R, Tol A, Yekaninejad MS, Yidana A. Assessing the impact of an educational intervention program on sexual abstinence based on the health belief model amongst adolescent girls in Northern Ghana, a cluster randomised control trial. Reprod Health [Internet]. 2019 [cited 2020 Jul 6]; 16. Available from: https://www.ncbi.nlm.nih.gov/pmc/articles/ PMC6694566/.

24. Ndabarora E, Mchunu G. Factors that influence utilisation of HIV/ AIDS prevention methods among university students residing at a selected university campus. SAHARA-J J Soc Asp HIVAIDS [Internet]. Taylor \& Francis; 2014 [cited 2020 Jul 6]; 11: 202-210. Available from: https://doi.org/10.1080/17290376.2014.986517.

25. Khani Jeihooni A, Arameshfard S, Hatami M, Mansourian M, Kashfi SH, Rastegarimehr B, et al. The effect of educational program based on health belief model about HIV/AIDS among high school students. Int J Pediatr 2018; 6: 7285-7296.

26. Tang J, Gao X, Yu Y, et al. Sexual Knowledge, attitudes and behaviors among unmarried migrant female workers in China: a comparative analysis. BMC Public Health 2011; 11: 917.

27. Buldeo P, Gilbert L. Exploring the Health Belief Model and first-year students' responses to HIV/AIDS and VCT at a South African university. Afr J AIDS Res AJAR 2015; 14: 209-218.

28. Garett R, Smith J, Chiu J, Young SD. HIV/AIDS stigma among a sample of primarily African-American and Latino men who have sex with men social media users. AIDS Care 2016; 28: 731-735.

29. Tarkang EE, Pencille LB. Psychosocial predictors of consistent condom use among migrant road construction workers in the Southwest Region of Cameroon using the Health Belief Model. Pan Afr Med J [Internet]. 2018 [cited 2019 Jun 14]; 29. Available from: https://www.ncbi.nlm.nih.gov/pmc/articles/PMC6080963/

30. Wang Y, Cochran C, Xu P, et al. Acquired immunodeficiency syndrome/human immunodeficiency virus knowledge, attitudes, and practices, and use of healthcare services among rural migrants: a cross-sectional study in China. BMC Public Health 2014; 14: 158.

31. Yang B, Wu Z, Schimmele CM, Li S. HIV knowledge among male labor migrants in China. BMC Public Health 2015; 15: 323.

32. Aung HP, Panza A. Factors influencing sexual behaviors among youth Myanmar migrant workers in Samut Sakhon, Thailand. J Health Res 2016; 30: S45-51.
33. Loganathan T, Chan ZX, de Smalen AW, Pocock NS. Migrant women's access to sexual and reproductive health services in Malaysia: a qualitative study. Int J Environ Res Public Health 2020; 17: 5376.

34. Dahal S, Pokharel PK, Yadava BK. Sexual behavior and perceived risk of HIV AIDS among returnee labor migrants from Overseas in Nepal. Retrovirology [Internet]. 2012 [cited 2020 Dec 3]; 9. Available from: https://retrovirology.biomedcentral.com/articles/10.1186/1742-4690-9-S1-P106.

35. Suresh J. Knowledge and risk perceptions about hiv/aids among nepalese migrants in gulf countries: a cross-sectional study. Health Sci J [Internet]. iMedPub; 2014 [cited 2020 Dec 3]; 8. Available from: https://www.hsj.gr/abstract/knowledge-and-risk-perceptionsabout-hivaids-among-nepalese-migrants-in-gulf-countries-acrosssectional-study-2653.html.

36. Najimudeen M, Hla Myint M, Mie M, Akter M. HIV/AIDS among Migrant Workers in Malaysia. Sch Int J Obstet Gynecol 2020; 1-3. doi: 10.36348/sijog.2020.v03i01.001.

37. Yaya S, Bishwajit G, Danhoundo G, Shah V, Ekholuenetale M. Trends and determinants of HIV/AIDS knowledge among women in Bangladesh. BMC Public Health [Internet]. 2016 [cited 2020 Jul 6]; 16: 812. Available from: https://doi.org/10.1186/s12889-016-3512-0.

38. Bharat S, Ramakrishna J, Heylen E, Ekstrand ML. Gender-based attitudes, HIV misconceptions and feelings towards marginalized groups are associated with stigmatization in Mumbai, India. J Biosoc Sci 2014; 46: 717-732.

39. Surgevil O, Akyol EM. Discrimination against people living with HIV/AIDS in the workplace: Turkey context. Equal Divers Incl Int J Birm 2011; 30: 463-481.

40. Alwafi HA, Meer AMT, Shabkah A, et al. Knowledge and attitudes toward HIV/AIDS among the general population of Jeddah, Saudi Arabia. J Infect Public Health 2018; 11: 80-84.

41. Haroun D, El Saleh O, Wood L, Mechli R, Al Marzouqi N, Anouti S. Assessing Knowledge of, and Attitudes to, HIV/AIDS among University Students in the United Arab Emirates. PLoS One 2016; 11: e0149920.

42. Kuete M, Huang Q, Rashid A, et al. Differences in Knowledge, Attitude, and Behavior towards HIV/AIDS and Sexually Transmitted Infections between Sexually Active Foreign and Chinese Medical Students. BioMed Res Int 2016; 1-10.

43. Arrey AE, Bilsen J, Lacor P, Deschepper R. Perceptions of stigma and discrimination in health care settings towards sub-saharan african migrant women living with hiv/aids in belgium: a qualitative study. J Biosoc Sci 2017; 49: 578-596.

44. Vorasane S, Jimba M, Kikuchi K, et al. An investigation of stigmatizing attitudes towards people living with HIV/AIDS by doctors and nurses in Vientiane, Lao PDR. BMC Health Serv Res Lond [Internet]. 2017 [cited 2019 Jun 15]; 17. Available from: http:// search.proquest.com/docview/1873435933/abstract/50052FE26C6141E8PQ/3.

45. Ruiz Y, Guilamo-Ramos V, McCarthy K, Muñoz-Laboy MA, de López MLR. Exploring Migratory Dynamics on HIV Transmission: The Case of Mexicans in New York City and Puebla, Mexico. Am J Public Health Wash 2014; 104: 1036-1044.

46. Amirkhanian YA, Kuznetsova AV, Kelly JA, et al. Male Labor Migrants in Russia: HIV Risk Behavior Levels, Contextual Factors, and Prevention Needs. J Immigr Minor Health 2011; 13: 919-928.

47. Weine S, Bahromov M, Loue S, Owens L. HIV Sexual Risk Behaviors and Multilevel Determinants Among Male Labor Migrants from Tajikistan. J Immigr Minor Health 2013; 15: 700-710.

48. Thapa S, Pathak S, Leppin A, et al. Factors Associated With Condom Use for HIV Prevention Among Nepalese Labor Migrant Couples. AIDS Educ Prev 2016; 28: 180-190.

49. Akinsulure-Smith AM. Exploring HIV Knowledge, Risk and Protective Factors Among West African Forced Migrants in New York City. J Immigr Minor Health 2014; 16: 481-491. 
50. Denison HJ, Bromhead C, Grainger R, Dennison EM, Jutel A. Barriers to sexually transmitted infection testing in New Zealand: a qualitative study. Aust N Z J Public Health [Internet]. 2017 [cited 2020 Jul 16]; 41: 432-437. Available from: https://onlinelibrary.wiley.com/doi/abs/10.1111/1753-6405.12680.

51. Manirankunda L, Loos J, Alou TA, Colebunders R, Nöstlinger C. "It's Better Not to Know": Perceived Barriers to Hiv Voluntary Counseling and Testing Among Sub-Saharan African Migrants in Belgium. AIDS Educ Prev N Y 2009; 21: 582-593. 